\title{
RELIGIOSITY OF CIREBONESE SOCIETY CULTURE IN THE ORAL TRADITION PEPUJIAN
}

\author{
Muhammad Kamaluddin ${ }^{1,2}$ \\ ${ }^{1}$ Muhammadiyah University of Cirebon \\ ${ }^{2}$ Phd Student of Linguistics Department, Indonesia University of Education, Bandung \\ *Corresponding author: enceque_kedawung@yahoo.com
}

\begin{abstract}
Article history
Received:14/09/2015

Received in revised form:14/09/2015

Accepted: 18/10/2015

Abstract

Cirebonese society and its culture grew and developed from a long history of the oldest Islamic Sultanate in West Java led by Sunan Gunung Jati. As the King of the Sultanate and at the same time called the Waliyullah, such a variety forms of tradition are held as the cultural expression of his citizen. One of it is the oral tradition pepujian. This tradition has been exist in the mid of the society until now. This research is conducted as a study of public religiosity. It is seen from the oral tradition pepujian is linked with the culture of the society. It is link with the idea of semiotics theory of Claude Lévi-Strauss (1904) in anthropology studies using language approach. The methodology used is paradigm from the qualitative research. Through the linguistics anthropology framework, researcher involves in the community activities and being part of them. So it is eventually discovered that the oral tradition pepujian in the culture of Cirebonese speakers is a verse of poetry containing Islamic teachings about faith and worship. It is spoken in the form of song as an expression of their cultural religiosity.
\end{abstract}

Keywords: Cirebonese society, culture, oral tradition, religiosity. 


\subsection{INTRODUCTION}

According to Kato (2011, p. xxvi), the world's largest Muslim nation, Indonesia was dominated by Hindu-Buddhist civilizations prior to the arrival of Islam in the archipelago. Geertz (quoted in Kato, 2011, p. xxvi) explained the characteristics of Islam in Indonesia:

“...Indonesian Islam, cut off from its centres orthodoxy at Mecca and Cairo, vegetated, another meandering tropical growth on an already overcrowded religious landscape. Buddhist mystic practices got Arabic names, Hindu Rajas suffered a change of title to become Moslem Sultans, and the common people called some of their wood spirits jinns; but little else changed."

Wahidin (1990: 92) said the disciples in the teachings of Islam usually hum the congregation pepujian on certain moments. One of the preferred times is ahead calling iqamat before the imam advancing the mihrab to lead the obligatory prayers in congregation. Meaning of pepujian itself is the oral tradition in the form of singing of a religious nature that is hum when waiting for the imam to come.

According to Muhaimin (2006: 97), usually after the call to prayer, worshipers at tajug (small mosque) sing pepujian with the chanting verses while awaiting the arrival of other pilgrims in order to jointly implement the congregational prayers. Meanwhile other pilgrim conducts the sunnah prayers before the prayers priest stands in the sanctuary and ready to lead the congregational prayers. This has turned out to be an oral tradition of the Cirebonese speaker as a characteristic of their religious culture which is interesting to study.

The study also going to review the connection between languages and culture that are previously been done by Ilić (2004). In the article he said people are often having those various thoughts about the world in form of speech-language. This is why he thinks, it is certain there is a relationship between language and the world of reality in the area of mind. This is said as an indicator of the golden years concerning the study of language. According to him, any study as well as the development of ideas and transfer of knowledge will never be able to happen without an intermediary language.

In addition, research on language and religion were also done by some scholars. Among them are Keane (1997) and Darquennes and Vandenbussche (2011). The first author expressed about the practice of religious in speaking. In this issue, Keane explained that the practice of language in question will not be separated from what is called the action, text and context. According to him, the religious question is a matter that is motivated by the subjective experience of a person about anything that cannot be reached by the five senses. Furthermore, he said various forms of activity such as speaking, singing, reading, writing and etcetra called an act of speaking in response to a religious experience that cannot be identified earlier.

For the latter, as mentioned above, in their article Darquennes and Vandenbussche (2011) reviewed the studies on the areas of language and religion in the disciplines of sociolinguistics. According to them, several sub-themes often review the link between language and religion and among others the language in the context of a particular religion, the sacred text, and the translation, the language of religion in the texts of religion, the use of the specific term of language in religion, language and beliefs and the religious aspect in the study of languages. As an example what I have just mentioned earlier is the study of mantras, hymns, and prayers in a religious curse.

About the study, it is found the discussion on the semiotic relation to culture and society is what has been published by Backer (2007) and Berger (2014). In this topic, Backer reviewed signs and meanings of contemporary dance in Malaysia. The dance is referred in writings that no other dance works by choreographers such as dances Berkumandangnya Qasidah by Redza, Nusantara by Mew Chang Tsing, and Gui Qu Lai Xi by Loke Soh Kim. He said a variety of dances, from the standpoint of semiotics found that various signs indicated through motions, setting the stage, the choice of costumes, ornaments make up, music, and various elements of 
other support in a dance performance that implies gender equality, cultural identity, and religion are the idea of its choreographers.

Meanwhile, the study of semiotics relation to society is what was once done by Berger (2014). In his research, he found the relationship between the sign and its meaning is an agreement of a society. That is, between the sign and the meaning is not wholly natural. To understand it, we need a society as an institution of understanding of what is contained by a variety of signs surrounding the community.

Thus, the poems in the Cirebon language pepujian are to be studied in this paper. It is the culture of oral tradition that grew and developed by generations in the midst of a pluralistic society. Over time, the oral tradition is also considered a culture of Cirebonese religious communities. Religiosity is shown through series of verses of poem containing the teachings of Islamic faith and worship.

\subsection{THEORETICAL FRAMEWORK}

To say a culture is a form of communication means to see it as a system of signs. This is the semiotic theory of culture. In its most basic version, this view holds that culture is a representation of the world, a way of making sense of reality by objectifying it in stories, myths, descriptions, theories, proverbs, artistic products and performances. In this perspective, people's cultural products, e.g: myths, rituals, classification of the natural and social world, can also be seen as an example of the appropriation of nature by humans through their ability to establish symbolic relationships among individuals, groups, or species (Duranti, 1997, p. 33).

In the other hand, the science of signs is called semiotics, a sign being anything that can be used to stand for something else. There are two "founding fathers" of semiotics, the Swiss linguist Ferdinand de Saussure and the American philosopher Charles Sanders Peirce. Saussure divided signs into two parts: every sign is made of sound-images or signifiers and the concepts generated by the signifiers, signified. Peirce explained there are three kinds of signs: icons, indexes, and symbols. Icons signify by resemblance, indexes signify by cause and effect, and symbols signify on the basis of convention (Berger, 2014, pp. 22-23).

Regarding this linguistic discipline it should be noted that the link between linguistics and anthropology dated back to the structuralism of Ferdinand de Saussure, which laid the basis for a new approach in sociology and anthropology. Also influential was de Saussure's idea of language as a system of mutually defining entities and, especially, his theory of meaning with the notions of signifier, signified, and sign, where meaning is not accorded by a simple correspondence of a sign to an external object, but by the relation of the sign to the whole code of signification (Ilić, 2004, p. 4).

Therefore the structuralist anthropologist Claude Lévi-Strauss who found the earliest examples of the view of culture as communication suggested that not only language, but culture itself could be looked upon as a code of meaning in de Saussure's sense. According to him, all cultures are sign systems that express deeply cognitive predispositions to categorize the world in terms of binary oppositions (Duranti 1997, Ilić 2004).

For instance, binary oppositions are shown by the words "inside" and "outside" words, batin and lair (terms borrowed, as a matter of fact, from the sufi tradition of Muslim mysticism, but locally reworked) refer on the one hand to the felt realm of human experience and on the other hand to the observed realm of human behaviour (Geertz, 1983, p. 60).

In the other hand, signs stand in for or represent concepts and can be understood as marks and noises that generate or carry meaning through their relationship with other signs. The study of signs and the way they work is the domain of semiotics wherein the components of a sign are called the signifier and signified (Barker, 2004, p.183). 
A sign may stand for something to somebody, who will be called the interpreter. But a sign only functions as such to the interpreter in virtue of the interpreter's understanding that does so function, and this understanding is called interpretant. An example is given in the figure below.

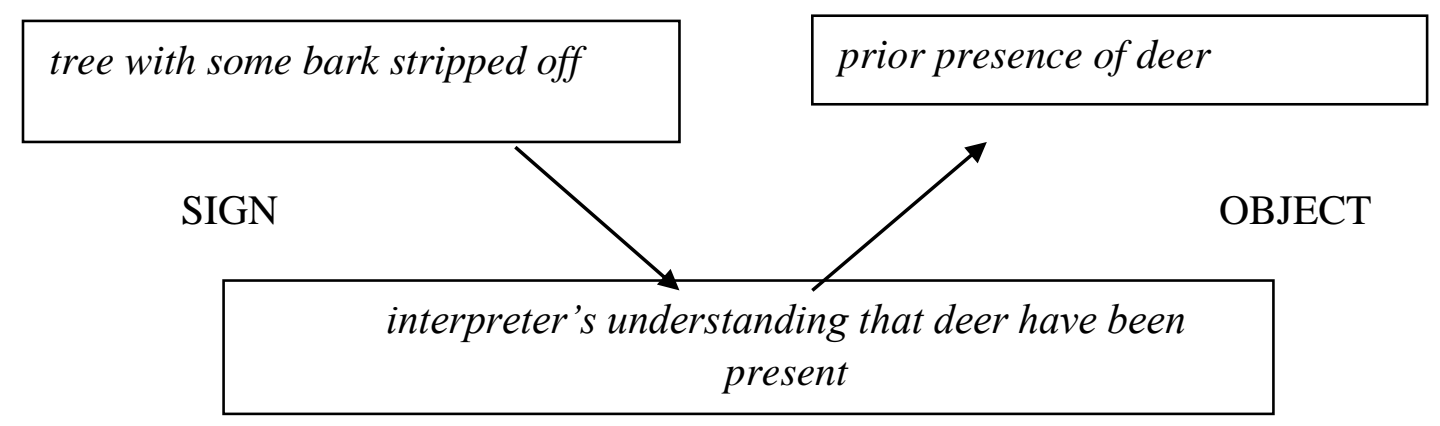

\section{INTERPRETAN}

Figure 1. Interpreting a sign

The stripped bark of a tree, which is all that the interpreter can see, gives her or him further knowledge, namely knowledge that a deer has been presented; because $\mathrm{s} / \mathrm{he}$ understands it is a sign of its prior presence. The sign thus brings the interpreter into cognitive contact with the deer (Malmkjaer, 2001, pp. 536-537). Lévi-Strauss starts from the assumption that everywhere a human has the same mind and cultures have different implementations of basic abstract logical properties of thinking which are shared by all humans and adapted into specific living conditions (Duranti, 1997, p. 33).

The issue then becomes the extent to which the same types of combinations or substitutions are found in a variety of different cultures. If they are found in historically unrelated societies, the anthropologist may see these associations as a universal category of human thought. In this method, there are notions taken from a linguistic theory can be used in cultural analysis because culture is understood as a system which communicates itself through social actors. Lévi-Strauss believed people does not communicate through myths, but myths communicate through people (Duranti, 1997, p. 35).

\subsection{METHODOLOGY}

This research is conducted with a qualitative paradigm. Then, linguistic anthropology is used as the method to gain data in the field of research. Duranti (1997) introduced linguistic anthropology as an interdisciplinary field which studies language as a cultural resource and speaking as a cultural practice. According to Héc (1979 quoted in Ilić, 2004, p. 3), it is usually what one first thinks of when talking about the relationship between language and culture. It studies language variations and uses in relation to the cultural patterns and beliefs and relies heavily on theories, methods and findings of anthropology.

The data used in this study is a poem pepujian in the oral tradition of Cirebonese society. The data is obtained directly by the researcher from the community speech in various regions and the city of Cirebon regency. In this case, the researcher as the main instrument of research conducted each phase independently in the field. Thus, the data obtained were then analyzed according to the theory used. So finally this study led to the conclusion on the issues serve as the main topic of research. 


\subsection{FINDING AND DISCUSSION}

In Cirebonese society, the time after the call to prayer (azan) before the obligatory prayers in congregation is often used to chant pepujian. Poetries sung it typically in Cirebon language. There are also some that is mixed with shalawat poetry in Arabic.

Here are five poems of pepujian in Cirebon language used as research data.

\#1 dikentongi diazani ora teka

'called by azan does not come'

iku wong bakal cilaka

'the people would be damned'

dawuh Nabi sekabeh umat

'The Prophet (Muhammad SAW) said to all people'

umat Islam aja tinggal salat

'Muslims do not leave prayer'

tinggal salat siksane berat

'leaving prayers punished weightly'

besuk ning alam akherat

'later in the hereafter'

sugih sawah sugih mobil

'rich of rice rich of car'

besuk mati tunggangane katil

'tomorrow death driving katil'

harta benda ora ngintil

'treasures do not participate'

sing ngintil amal secuil

'what participates a bit of charity'

\#2 eling-eling umat

'please remember all people'

muslimin muslimat

'all of men and women muslim'

ayo kita salat berjamaah ....

'let us pray together ...'

iku kewajiban kita umat Islam

'it is our duty as the muslim'

kanggo bekal mengko

'for lunch later'

ning alam akhirat

'in the hereafter'

\#3 eman-eman temen

how a pity'

wong ganteng bli sembahyang

'handsome people do not pray'

Nabi Yusuf ganteng

'Prophet Yusuf is handsome'

ya gelem sembahnyang

'yes want to pray'

eman-eman temen

'how a pity'

wong sugih bli sembahnyang

'rich people do not pray'

Nabi Ayub sugih 


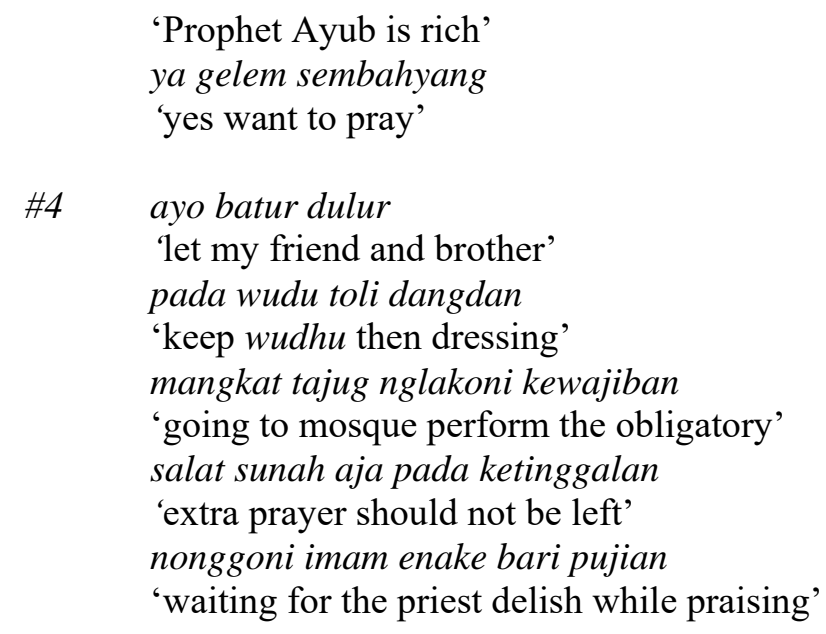

For the people of Cirebon, the lyrics of four paragraph of pepujian (\#1, \#2, \#3, and \#4) above contain the teachings of Islam in the aspect of worship. Especially prayers delivered as a form of worship with the value exceeds the principal treasures of the world. In this case the Islamic doctrines of death, hell, the torment, world, fail, poor, and disobedient on one side will be the opposite of the values of life, heaven, the reward, hereafter, care, rich, and obedient on the other side. More details can be seen in the table below.

\begin{tabular}{|l|l|}
\hline \multicolumn{2}{|c|}{ Binary oppositions of Lévi-Strauss } \\
\hline death & life \\
\hline hell & heaven \\
\hline torment & reward \\
\hline world & hereafter \\
\hline fail & care \\
\hline poor & rich \\
\hline disobedient & obedient \\
\hline
\end{tabular}

Tabel. 1 Islamic Doctrines in The Aspect of Worship

\#5 duh Gusti, kula
'oh God, I'm'
sanes ahli surga
'not a heaven expert'
namung boten kiat
but not strong at all'
mlebu ing neraka
'going to the hell'
duh Gusti, kula
'oh God, I'm'
nyuwun pangampura
beg Your forgiveness'
sekatahe dosa
'of sins just as much'
ingkang sampun lewat
'which have passed'

As for the above lyrics of pepujian (\#5), it contains Islamic teachings on the aspect of faith. In this case, the main conviction of a Muslim will be the arrival of the hereafter after a life in this world. Just surrender to God will reward her/his deeds and finally add to her/his belief. Islamic doctrines regarding heaven, hell, sin, reward, torture, forgiveness will always be presented in tandem for human 
life. In the end, s/he will get only one of the two things in the binary opposition. More details can be seen in the table below.

\begin{tabular}{|l|l|}
\hline \multicolumn{2}{|c|}{ Binary oppositions of Lévi-Strauss } \\
\hline heaven & hell \\
\hline reward & sin \\
\hline forgiveness & torture \\
\hline
\end{tabular}

Tabel. 2 Islamic Doctrines in the Aspect of Faith

The main point here, the values of Islam is always an ingredient in a variety of preaching discourse. Its presence varies according to the context. For example, in a pepujian, it presents a preaching discourse of worship and faith values. Both works together with depictions of the signs of Islamic teachings which are substantially sung before the prayers began. The following figure is how to interpret pepujian.

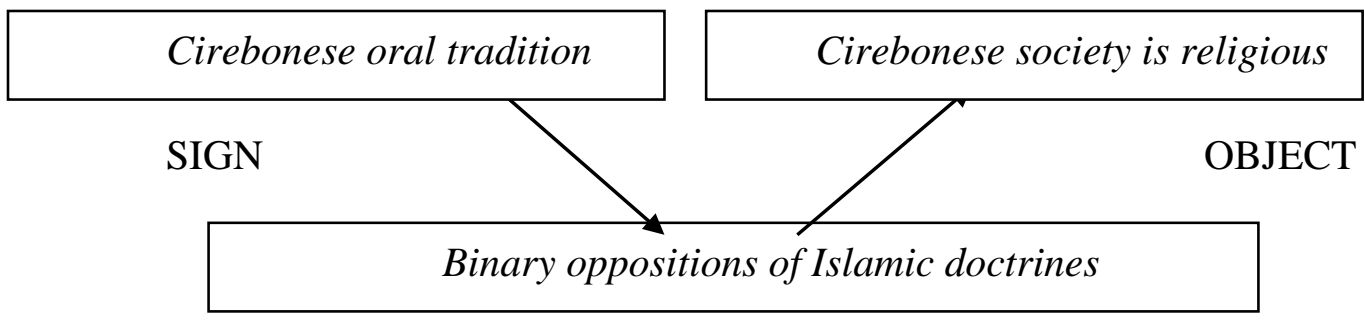

INTERPRETAN

Figure. 2 Interpreting Pepujian

Thus, the form of interpretation to whatever cultural forms subjectively returned to any reader of the sign. It is not always a matter which has been agreed or must be followed. Opportunities to provide new and different interpretation of the existing ones remain open. It is rationalize in accordance with the facts and realities exist in the culture of society stakeholders.

\subsection{CONCLUSION}

Pepujian is a medium of preaching using Islamic signs in the realm of worshipping and faith in small rural tajug-tajug even urban mosques in Cirebon. The fact is, there are some Cirebonese people who claim they do not feel the "thrill" while listening the Islamic preaching when it is not delivered in their language. Nonetheless, it seems to compliment the oral tradition which is still favored by those who are considered as the traditional Muslims. In other words, times and intellectuals bring modern Muslim societies to practice the Islamic teachings substance rather than merely rituals. Thus, both individual and society of traditional and modern Muslims, they will always show signs as indicators of their religiosity. Religiosity can be seen from the Islamic values of heaven, hell, life, death which is always sung with the language of Cirebon just before prayers.

\section{ACKNOWLEDGMENT}

I would like to say a grateful thank to Prof. Dr. H. Khaerul Wahidin, M.Ag. as the Rector of Muhammadiyah Cirebon University for the guidance and direction in this research. I also very thank to Datok Prof. Mifedwil Jandra for the opportunity to publish the result of this research in the Journal of Faculty of Islamic Civilization of University Technology Malaysia. Hopefully useful, amen. 


\section{References}

Backer, Mumtaz Begum Aboo. (2007). Semiotics: Signs and Meanings in Contemporary Dance in Malaysia. Journal of Arts and Discourse. Vol. 6: pp. 71-76.

Barker, Chris. (2004). The SAGE Dictionary of Cultural Studies. London: SAGE Publication Ltd.

Berger, Arthur Asa. (2014). Semiotics and Society. Symposium: Signs, Symbols, and Semiotics 51: pp. 22-26.

Darquennes, Jeroen. and Vandenbussche, Wim. (2011). Language and Religion as A Sociolinguistics Field of Study: Some Introductory Notes. Sociolinguistics 25: pp. 1-11.

Duranti, Allesandro. (1997). Linguistic Anthropology. New York: Cambridge University Press.

Geertz, Clifford. (1983). Local Knowledge: Further Essays in Interpretive Anthropology. New York: Basic Books, Inc.

Ilić, Biljana Mišić. (2004). Language and Culture Studies - Wonderland through The Linguistic Looking Glass. Linguistics and Literature. Vol. 3 (1): pp. 1-15

Kato, Hisanori. (2011). A Constructionist Approach to Current Islamic Movements in Indonesia, in The Clash of Ijtihad Fundamentalist versus Liberal Muslims: The Development of Islamic Thinking in Contemporary Indonesia. Delhi: ISPKC. pp. xi-xxxvi.

Keane, Webb. (1997). Religious Language. Annual Reviews Anthropology 26: pp. 47-71.

Malmkjaer, Kirsten. (2001). The Linguistics Encyclopedia. London: Routledge.

Muhaimin, A. G. (2006). The Islamic Traditions of Cirebon: Ibadat and Adat among Javanese Muslims. Canberra: ANU Press.

Wahidin, Khaerul. (1990). Sebuah Etnografi Kehidupan Penganut Tarekat Naqsabandiyah Khalidiyah di Desa Tlogoharum. Laporan Penelitian Badan Litbang Departemen Agama RI. Tidak diterbitkan. 